\title{
Unremitting halitosis: A case of Olfactory Reference Syndrome
}

\author{
Süregen Ağız Kokusu: Olfaktör Referans Sendrom Olgusu
}

\author{
Murat Eren Özen ${ }^{1}$, Murat Aydın² \\ ${ }^{1}$ Dr., Özel Adana Hastanesi, Psikiyatri Kliniği, Adana \\ ${ }^{2} \mathrm{Dt}$. Ağız Kokusu Tanı Kliniği, Serbest Diş Hekimliği, Adana
}

\begin{abstract}
SUMMARY
Subjective halitosis is a chronic disorder and cannot ea sily be identified or measured by objective methods. The patients complaining with subjective halitosis usually refer to dentists, yet they reject to psychiatric consultations. One of its cause is Olfactory Reference Syndrome (ORS) which can be of anxiety, obsessional or delusional. ORS patients usually refer to others' behaviors; people's closing their mouth, coughing and touching their nose, opening window, turning faces to another side to protect themselves all give signs as to emitting malodor which patients misinterpret. This paper reports a 23-old female who suffers from halitosis since 3 years which is diagnosed as ORS and treaed with Clomipramine.
\end{abstract}

Key Words: Olfactory reference syndrome, obsessive thought, clomipramine, antidepressants, subjective halitosis, delusional halitosis

(Klinik Psikiyatri 2016;19:149-151)

DOI: $10.5505 / \mathrm{kpd} .2016 .36844$

\section{ÖZET}

Subjektif halitosis kronik ve kolayca tanı konamayan veya nesnel metotlar ile ölçülemeyen bir bozukluktur. Subjektif halitosis olan hastalar sıklıkla diş hekimleirne başvururlar, hatta psikiyatriste başvurmayı reddederler. Olfaktör referans sendrom (ORS) bunun sebeplerinden birisidir ve anksiyete, obsesyon veya paranoid şekillerde olabilir. ORS hastaları başkalarının davranışlarına atıfta bulunurlar; insanların ağızlarını kapatmaları, öksürme veya burunlarına dokunmaları, pencereyi açmaları, kafalarını başka yöne çevirmeleri hastaların koku yaydığını düşündürten işaretler olarak yanlış yorumlanabilir. $\mathrm{Bu}$ olgu sunumunda, 23-yaşında kadın hastanın 3 yıldır halitosis nedeniyle sıkıntı çektiği ve ORS tanısı konularak Klomipramin ile tedavi edildiği bildirilmektedir.

Anahtar Sözcükler: Olfaktör referans sendrom, obsesif düşünce, klomipramin, antidepresan, subjektif halitosis, delüsyonel halitosis 


\section{INTRODUCTION}

Halitosis is chronic, endogenous malodor and aetio logically classified from type $0-5$; physiologic, oral, airway, gastroesophageal, blood-borne and subjective respectively (Aydin and Harvey-Woolworth, 2014). The subjective halitosis is characterized by malodor can not be confirmed by the other, further, there is no local or systemic problem despite the patient's complaints. Cases of halitosis may be misdiagnosed by clinicians (as mcuh as $27 \%$ as indicated) (Falcao et al, 2012).

Subjective halitosis can appear in two clinical forms. Neurogenic (cacosmia-bad odor sense, phantosmia-imaginary odor sense, chemosensor dysfunctions) or pshycogenic (anxiety, obsessional or delusional disorders including Olfactory Reference Syndrome (ORS) Özen and Aydin, 2015). ORS is one of the conditions mentioned in the Diagnostic and Statistical Manual of Mental Disorders (DSM-V), (Kaplan HI, 2015) which is not categorized as a separate disorder, in which patients nongenuinely believe that they emit unpleasant odor include almost anything foul smelling are often from mouth, genitals, rectum, or skin (Kaplan and Saddock, 2015).

This case report illustrates a patient representing an ORS patient referred by halitosis clinics and evaluated by a psychiatrist which must be in the attention of medical settings (psychiatrists, earnose-throat specialists and dentists) and may be kept in mind during clinical and differential diagnosis processes.

\section{CASE REPORT}

23-years old, single, female, healthy patient complained from halitosis with 3-years history (approxi mately during the beginning of her 20s which conforms with the literature) which has not been interrupted even for few minutes. She did not perceive oral malodor herself but thought that people around her were closing their mouth, coughing, touching and rubbing their nose or ridiculing her by turning their face away. She thought that everybody hesitated to contact her or talk to her even when her mouth was closed. She stated that she was feeling better when -she was- alone.

She was regularly brushing her teeth and tongue, not smoker, drinker or taking any medications regu larly. Any systemic problem, including postnasal drip, enteric parasite, constipation, gastro esophageal reflux, allergy were not detected. Saliva volume was $2.5 \mathrm{ml} / \mathrm{minute}, \mathrm{pH}$ was found 6.5 and $\mathrm{H} 2 \mathrm{~S}$ level was less than $100 \mathrm{ppb}$ was found. Any dental caries, bad dental restoration, pathologic periodontal pocket, tongue coating were not detected. Cranial computerized tomography scan showed no pathology. Any biological cause which may explain halitosis was not found and the patient remained unremitted until psychiatric interventions.

Blood screens, cranial magnetic resonance imaging and electroencephalogram, neurological examinations did not reveal any pathological signs indicating neurological disorders such as epilepsy. No discordance was disclosed by her family members.

The case was diagnosed as ORS regarding her history and symptoms and signs. So far, he has not applied to a psychiatrist before and had not taken any psychotropic medications.

Clomipramine was initiated with/ as $75 \mathrm{mg}$ once daily and tolerated well. Although she showed some relief after 3 weeks with this treatment, addition of $75 \mathrm{mg}$ clomipramine during the second 3week interval resulted with $50 \%$ improvement. After 6 weeks, $225 \mathrm{mg} /$ day sustained for 6 weeks (totally 12 weeks) reaching a good result, as a consequence she began to socialize. Four-week interval monitoring (during next 12 weeks after first visit) revealed that her thoughts about others' behaviors and conversations between them changed and no social feedback to halitosis, or taking any reference behaviors were denoted with $225 \mathrm{mg} / \mathrm{d}$ of clomipramine after 5-month follow-up.

\section{DISCUSSSION}

Because of the clinical nature, reports and debates on ORS has not been decribed and/or discrimina ted yet, this clinical situation apart from deluisonal disorders, social phobia, obsessive compulsive di sorder and body dysmorphic disorder and requires/needs a clear definition (Cruzado et al, 2012). But, it is stated that fundamental problem is to outline the nature and existence of delusionality (Phillips, 1971). In some trends of psychiatric views on ORS; its conception is restricted to a mistaken judgment (Anglo-American); includes ideo-affective and perceptive phenomena (intuitions, interpretations, illusions, passion and imaginative exaltation) within the delusional phenomena (Continental European Psychiatry) (Ey et al, 1978); the essence of the delusion in the convictional certainty and absence of insight that other characteristics (extension, extravagance, pressure, affective response and influence) are not related with behavior (North American Psychiatry) (Oyebode F, 2008). In particular, the relation among ORS and other mental disorders are discussed and stressed elsewhere (Malasi, 1990; Davidson and Mukherjee, 1982; Masnik, 1983).

ORS has not been well separated from delusional disorders, or obsessive compulsive disorder (OCD) (Luckhaus et al, 2003). In particular, the relation 
among ORS and other mental disorders have been deeply discussed (Malasi, 1990; Masnik, 1983).

In this case, the closest diagnose is halitophobia. Halitophobic patients do not complain from halitosis, but they fear of having halitosis without referring others (Özen and Aydin, 2015). Second possib le diagnosis is OCD. To discriminate OCD, it is necessary at least one repetitive behavior (such as brushing teeth dozens time, smelling her own breath during the times with close friends many times every day) would be expected. Also, OCD patients think they emit malodor even when alone. This case mismatches such signs. Instead, the patient referred external abutments to her ma lodor.

In the literature, clomipramine (Kizu et al, 1984) and other tricyclic antidepressants (Brotman and Jenike, 1984) have been used to treat ORS cases. A patient which resisted to tranquilizers and a monoamine oxidase inhibitor has been reported (Phillips, 1971). This case responded well to clomipramine even in the first week.
Treatment should be monitorized by self-assessment or other people's assessments rather than halitometric examination, because complains are imaginary in subjective halitosis cases (Aydin, 2016).

Patients with halitosis apply firstly to dentists, but not to psychiatrists. Because of the complexity and difficulty in diagnosing, treating and patients' unawareness of halitosis and halitosis spectrum disorders, ear-nose-throat specialists, dentists and psychiatrists should be well trained on and aware of subjective forms of halitosis, especially with ORS and delusional forms of halitosis.

Yazışma adresi: Dr.Murat Eren Özen. Özel Adana Hastanesi, Psikiyatri Kliniği, Adana, drmuraterenozen@gmail.com

\section{REFERENCES}

Aydin M, Bollen CM, Özen ME (2016) Diagnostic Value of Halitosis Examination Methods. Compend Contin Educ Dent. 37(3):174-178

Aydin M, Harvey-Woodworth CN (2014) Halitosis: a new defi nition and classification. British Dental Journal. 217:E1

Brotman AW, Jenike MA (1984) Monosymptomatic hypochond riasis treated with tricyclic antidepressants. Am J Psychiatry 141:1608-1609.

Cruzado L, Cáceres-Taco E, Calizaya JR (2012) Apropos of an Olfactory Reference Syndrome case. Actas Esp Psiquiatr 40(4):234-8.

Davidson M, Mukherjee S (1982) Progression of olfactory re ference syndrome to mania: a case report. Am J Psychiatry 139:1623-1624.

Ey H, Bernard P, Brisset C (1978) Tratado de Psiquiatría. Barcelona: Elsevier Masson p. 448-71.

Falcao DP, Vieira CN, Batista de Amorim RFB (2012) Breaking paradigms: a new definition for halitosis in the context of pseudo-halitosis and halitophobia. J. Breath Res. 6(1):017105.

Kaplan HI, Sadock JB Delusional Disorder and Shared Psychotic Disorder (2015) In: B.J. Sadock, V.A. Sadock editors. Synopsis of Psychiatry: Behavioral Sciences/ Clinical Psychiatry.
Philadelphia: Wolters Kluwer; (11th ) pp.334-335.

Kizu A, Miyoshi N, Yoshida Y, Miyagishi T (1994) A case with fear of emitting body odour resulted in successful treatment with clomipramine. Hokkaido Igaku Zasshi 69:1477-1480.

Luckhaus C, Jacob C, Zielasek J, Sand P (2003) Olfactory refe rence syndrome manifests in a variety of psychiatric disorders. Int J Psychiatry Clin Pract. 7:41-4.

Malasi TH, El-Hilu SR, Mirza IA, El-Islam MF (1990) Olfactory Delusional Syndrome with Various Etiologies. Br J Psychiat 156:256-260.

Masnik R. Olfactory reference syndrome and depression (letter) (1983) Am J Psychiatry 140:670-671.

Oyebode F (2008) Sims' Symptoms in the mind. An introduction to descriptive psychopathology. Edinburgh: Saunders Elsevier p. 121-52.

Özen ME, Aydin M (2015) Subjective halitosis: definition and classification. J N J Dent Assoc 86(4):20 -24.

Phillips PW (1971) An olfactory reference syndrome. Acta Psychiatr Scand 47:484-509. 